\title{
Media Komunikasi Guru Terhadap Penyandang Tunarungu Selama Pandemi
}

\author{
${ }^{1}$ Trika Fitria, ${ }^{2}$ Sutamaji, ${ }^{3}$ Muhammad Amrillah \\ ${ }^{123}$ Nama IAI Pangeran Diponegoro Nganjuk \\ trikafitria57@gmail.com, ${ }^{2}$ sutamaji4@gmail.com, ${ }^{3}$ amrillah084@gmail.com
}

\begin{abstract}
ABSTRAK
Komunikasi merupakan suatu proses sosial yang mendasar dalam kehidupan manusia. Dalam berkomunikasi sering kali menemukan hambatan dalam proses penyampaian pesan. Khususnya berkomunikasi dengan seorang penyandang tunarungu yang mengalami gangguan pada pendengaran. Mengajar anak tunarungu diperlukan strategi tersendiri dalam penggunaan media pembelajaran. Apalagi selama pandemi Covid-19 dibutuhkan media pembelajaran yang efektif dari seorang guru kepada siswa tunarungu dalam mengajar dan memberikan intruksi pengetahuan sesuai dengan kurikulum yang ada disekolah. Salah satunya yaitu penggunaan media komunikasi nonverbal baik dilakukan dalam jaringan ataupun luar jaringan selama pandemi. Metode penelitian ini menggunakan pola penelitian deskriptif dan studi kasus dengan pendekatan kualitatif. Hasil penelitian menunjukan bawah media komunikasi guru dalam proses belajar mengajar terhadap siswa penyandang tunarungu selama pandemi di SDLB Shanti Kosala Mas Trip adalah berbentuk buku LKS yang telah dimodifikasi oleh guru sesuai tingkat ketunaan siswa dan Handphone sebagai alat dan sarana guru dengan siswa dan wali murid dalam proses pembelajaran selama pandemi agar tetap terjalin secara efektif. Sedangkan media yang digunakan yaitu internet dengan memanfaatkan aplikasi WhatsApp, Zoom Meeting dan Google Classroom.
\end{abstract}

Kata Kunci : Media Komunikasi, Tunarungu SDLB, Pandemi Covid-19

\section{PENDAHULUAN}

Berkomunikasi merupakan suatu hal yang mendasar bagi semua orang. Pada hakikatnya, komunikasi adalah proses pernyataan antara manusia, yang dinyatakan adalah pikiran atau perasaan seseorang kepada orang lain dengan menggunakan bahasa sebagai alat penyalurnya. Namun, seseorang akan tersadar bahwa komunikasi tidak akan menjadi mudah apabila terjadi gangguan komunikasi (noise), baik noise tersebut terjadi pada komunikator, ataupun komunikan itu sendiri. Situasi noise dapat mengakibatkan proses komunikasi yang berjalan tidak efektif. Manusia selalu menggunakan komunikasi sebagai alat untuk berinteraksi sosial. Namun ada beberapa orang mengalami gangguan dalam berkomunikasi. Beberapa orang mengalami gangguan atau hambatan komunikasi dengan faktorfaktor gangguan yang berbeda. Salah satunya orang yang mengalami gangguan komunikasi dalam berinteraksi sosial adalah anak berkebutuhan khusus seperti anak tunarungu. 
Dalam berkomunikasi diperlukan adanya sarana atau media untuk menjembatani antara komunikator dan komunikan agar proses komunikasi yang berlangsung dapat berlangsung secara baik. Penggunaan media komunikasi itu sendiri merupakan segala sesuatu yang dapat digunakan untuk menyalurkan pesan sehingga dapat merangsang pikiran dan perasaan yang menarik perhatian, sehingga proses komunikasi dapat berjalan efektif.

Media komunikasi juga sangat diperlukan oleh guru terhadap anak berkebutuhan khusus seperti penyandang tunarungu. Seperti yang peneliti lihat di masa pandemi sekarang ini, media komunikasi memang benar diperlukan adanya. Adapaun berbagai media komunikasi yang dapat digunakan guru terhadap anak tunarungu adalah media tulisan dan membaca sebagai sarana penerimaan anak tunarungu, penggunaan isyarat sebagai media, serta gambar dan warna yang juga diperlukan untuk berkomunikasi oleh anak tunarungu.

Komunikasi juga dibedakan menjadi dua, yaitu komunikasi verbal dan komunikasi non-verbal. Komunikasi verbal merupakan proses komunikasi dimana pesan disampaikan dengan menggunakan kata-kata, begitu sebaliknya komunikasi non-verbal merupakan proses komunikasi dimana pesan disampaikan tidak menggunakan kata-kata. Contoh komunikasi non-verbal yaitu penggunaan ekspresi wajah marah ataupun bahagia tanpa menggunakan kata-kata. Kegiatan komunikasi dilaksanakan dengan menggunakan lambang atau kode. Kode yang sebagian besar digunakan dalam komunikasi adalah kode yang diucapkan atau ditulis (kode yang berhubungan dengan penggunaan kata-kata). Tetapi sesungguhnya masih ada kode lain yang sangat penting peranannya dalam komunikasi, yaitu kode nonverbal, atau kode tanpa kata.

Proses komunikasi yang terhambat seringkali ditemukan pada interaksi komunikasi yang melibatkan anak-anak seperti tunarungu. Hal ini disebabkan karena terhambatnya bahasa yang seharusnya mereka dapatkan melalui pendengaran. ${ }^{1}$ Hambatan dalam komunikasi tersebut, berakibat juga pada hambatan dalam proses pendidikan dan pembelajaran anak tunarungu. Menurut Delphie Anak Tunarungu adalah anak yang memiliki hambatan dalam pendengaran baik permanen maupun tidak permanen dan biasanya memiliki hambatan dalam berbicara sehingga mereka biasa disebut tunawicara. ${ }^{2}$ Anak tunarungu akan memiliki hambatan dalam komunikasi verbal/lisan, baik itu secara ekspresif (berbicara) maupun reseptif

\footnotetext{
${ }^{1}$ Novita Wuwungan, Peran Komunikasi Interpersonal Guru Dan Siswa Tunarungu Dalam Meningkatkan Sikap Kemandirian Anak Berkebutuhan Khusus Di Sekolah Pembina Luar Biasa Provinsi Kalimantan Timur, Ejournal Ilmu Komunikasi (Online) IV 4, 2016, Https://Ejournal.Ilkom.Fisipunmul.Ac.Id/Site/Wpcontent/Uploads/2016/11/JURNAL\%20O NLINE\%20(11-24-16-02-40-17).Pdf (6 April 2021)

${ }^{2}$ Fatma Laili Khoirun Nida, Komunikasi Bagi Anak Berkebutuhan Khusus, AtTabsyir Jurnal Komunikasi Penyiaran Islam (Online) I 2, 2013 , Https://Journal.Iainkudus.Ac.Id/Index.Php/Komunikasi/Article/View/431/455 $\quad(6 \quad$ April 2021)
} 
(memahami pembicaraan orang lain). Hambatan yang dialami oleh anak tunarungu mulai dari hambatan yang ditimbulkan dari penyesuaian kurikulum dengan pembelajaran daring, sarana dan prasarana yang kurang mendukung, kurangnya antusias siswa, dan sebagainya.

Anak tunarungu sudah pasti memerlukan pendidikan khusus. Pendidikan khusus yang seperti tercantum dalam UU No. 20 tahun 2003 Pasal 32, adalah pendidikan bagi peserta didik yang memiliki tingkat kesulitan dalam mengikuti proses pembelajaran karena kelainan fisik, emosional, mental, sosial atau memiliki potensi kecerdasan dan bakat istimewa. Layanan khusus untuk anak yang memerlukan pendidikan khusus disesuaikan dengan jenis kelainan yang disandang. ${ }^{3}$

Kegiatan pembelajaran disekolah dilingkungan anak-anak berkebutuhan khusus tentu tidaklah mudah, apalagi dimasa pandami saat ini segala kegiatan belajar mengajar dituntut oleh pemerintah untuk dilakukan dirumah tanpa harus ber tatap muka secara langsung, melainkan melalui media pembelajaran dengan memanfaatkan teknologi online atau media yang lain seperti pembelajaran jarak jauh, agar memutus rantai penyebaran Covid-19.

Pandemi merupakan suatu fenomena alam berupa musim wabah atau penyakit yang sangat merugikan masyarakat dunia. Pandemi Covid-19 yang terjadi saat ini banyak membawa dampak negatif yang luar biasa menyedihkan. Indonesia merupakan salah satu negara yang terpapar virus covid-19 dengan prosentase tinggi. Dampak negativ dari pandemi memang dirasakan langsung oleh seluruh lapisan masyarakat. Salah satu dampak nyata pandemi terjadi pada dunia pendidikan. Tentu hal ini membawa perubahan yang sangat drastis pada metode pembelajaran pendidikan di tanah air, tak terkecuali di sekolah luar biasa yang memang sebelum masa pandemi datang, sudah banyak memiliki hambatan dalam proses belajar mengajar disekolah. Dimasa pandemi sekolah anak berkubutuhan khusus harusnya juga mendapat perhatian lebih dari pemerintah, karna para pengajar harus lebih ekstra dalam melakuakn kegiatan proses belajar mengajar tanpa harus bertatap muka dengan anak didik secara langsung.

Dampak atau Imbas dari pandemi dirasakan langsung baik guru, siswa, dan wali murid. Dalam proses belajar wali murid juga harus pro aktif dalam mendukung kegiatan belajar mengajar secara daring maupun luring. Tenaga pengajar atau Guru harus lebih sering berkomunikasi terhadap wali murid guna berjalannya proses belajar secara efektif. Karna setiap anak memiliki tingkat dan jenis ketunaan yang berbeda baik guru maupun wali murid harus sering berkomunikasi dalam

${ }^{3}$ Asriani Alimuddin, Schancya Gillian Wairata, Efektivitas Komunikasi NonVerbal Pada Anak Tunarungu Dalam Berkomunikasi Di Slb Rajawali Makassar, Al-Qisthi Jurnal Sosial Dan Politik-Sekolah Tinggi Ilmu Sosial Dan Politik ( STISIP) Muhammadiyah Sinjai-Sulawesi Selatan (Online) XIII 1, 2018, Hitp:/StisipmSinjai.Ac.Id/Stisippublishing/Index.Php/JAQ/Article/View/135(6 April 2021) 
mendiskusikan media apa yang mudah diterima dan diserap oleh anak berkubutuhan khusus.

Anak berkubutuhan khusus itu sendiri tidak hanya penyandang tunarungu saja. Banyak jenis dan penggolongan dalam menentukan ketunaan seseorang. Namun disini penulis memilih penelitian terhadap anak penyandang tunurungu. Dalam penelitian ini akan membahsas tentang bentuk dan media apa saja yang digunakan guru, sebagai alat komunikasi yang diterapkan pada penyandang tunarungu selama pandemi. Meskipun anak tunarungu tidak dapat mendengar dan berbicara akan tetapi mereka mempunyai maksud dan tujuan untuk mengutarakan isi hatinya atau untuk menyampaikan pesan kepada orang lain dengan bahasa tubuhnya sendiri. Sehingga proses komunikasi dapat berlangsung secara efektif, baik dalam berinteraksi dengan orang-orang sekitar dalam kehidupan sehari-hari, maupun penangkapan dan penyerapan materi pembelajaran selama proses belajar.

SDLB Shanti Kosala Mas Trip merupakan salah satu sekolah luar biasa di Kabupaten Nganjuk, mereka mendidik anak berkebutuhan khusus seperti anak penyandang tunarungu. Dibutuhkan kemampuan khusus seorang guru tentang bagaimana mengajar dan mendekatkan diri pada siswa penyandang tunarungu dalam proses belajar mengajar. Sehingga bisa terjadi interaksi yang baik diatara keduanya dan saling memahami makna komunikasi yang terjadi. SDLB Shanti Kosala Mas Trip merupakan salah satu sekolah yang terdampak pandemi covid-19. Guru, dan siswa diwajibkan belajar mengajar secara jarak jauh dengan memanfaatkan media yang tersedia.

\section{METODE PENELITIAN}

Dalam penelitian ini penulis menggunakan jenis penelitian kualitatif. Yaitu mengeksplorasi bagaimana model media komunikasi pendidikan anak tunarungu di SDLB Shanti Kosala Mas Trip selama pandemi Covid-19. Dalam pengumpulan data, peneliti mengambil data langsung di lembaga tersebut melalui prosedur dan teknik pengambilan data yang berupa observasi, wawancara, dokumentasi, maupun penggunaan instrument pengukuran lainnya yang khusus dirancang sesuai dengan tujuan peneliti.

Sifat penelitian yang digunakan dalam penelitian ini adalah deskriptif, dengan menggambarkan sebuah fenomena pada siswa penyandang tunarungu dan guru pengajar tunarungu secara menyeluruh, serta mencoba mengkaji secara mendalam dan terperinci. Jenis penelitian yang digunakan dalam penelitian ini adalah penelitan lapangan, yaitu suatu jenis penelitian yang mempelajari secara intensif tentang latar belakang masalah, keadaan dan posisi suatu pristiwa yang sedang berlangsung dilapangan, serta interaksi langsung di tempat penelitiann. 


\section{HASIL DAN PEMBAHASAN}

\section{Media Komunikasi Guru Dengan Siswa Tunarungu Selama Pandemi}

Dalam komunikasi, "pernyataan dinamakan pesan (message), orang yang menyampaikan pesan disebut komunikator (communicator), sedangkan orang yang menerima pernyataan diberi nama komunikan (communicate)". 4 Untuk lebih jelasnya, komunikasi memiliki arti proses penyampaian pesan oleh komunikator kepada komunikan. Dalam penelitian kali ini guru sebagai komunikator, menyampaikan pesan melalui media komunikasi terhadap siswa penyandang tunurungu dan juga wali murid.

Kegiatan komunikasi dalam pembelajaran siwa tunarungu dilaksanakan dengan menggunakan lambang atau kode. Lambang dan kode merupakan suatu media komunikasi yang dibutuhkan oleh siswa penyandang tunarungu. Bentuk dari pada media komunikasi bagi anak tunarungu sangat beragam. Bentuk dari media tersebut dapat berupa bentuk verbal dan non verbal. Media adalah segala sesuatu yang dapat digunakan untuk menyalurkan pesan dari pengirim ke penerima sehingga dapat merangsang pikiran, perasaan dan minat serta perhatian siswa sedemikian rupa sehingga proses belajar terjadi. ${ }^{5}$

Jadi media merupakan alat perantara yang sengaja dipilih komunikator untuk menghantarkan pesan komunikator agar sampai ke komunikannya. Sedangkan komunikasi verbal yaitu komunikasi yang menggunakan kata-kata dalam penyampaian pesan atau informasinya. Sementara komunikasi non verbal merupakan komunikasi yang menggunakan gerakan atau isyarat. Media yang sering digunakan terhadap siswa penyandang tunarungu selama pandemi covid-19 adalah media visual, visual artinya segala sesuatu yang dapat dilihat. Komunikasi visual masuk dalam kategori bentuk komunikasi verbal.

Menurut Kusrianto (2009:10-12) komunikasi visual adalah komunikasi menggunakan bahasa visual, dimana unsur bahasa visual (yang menjadi kekuatan utama dalam penyampaian pesan) adalah sesuatu yang dapat dilihat dan dapat dipakai untuk menyampaikan arti, makna atau pesan. ${ }^{6}$

\footnotetext{
${ }^{4}$ Asriani Alimuddin, Schancya Gillian Wairata, Efektivitas Komunikasi NonVerbal Pada Anak Tunarungu Dalam Berkomunikasi Di Slb Rajawali Makassar, Al-Qisthi Jurnal Sosial Dan Politik-Sekolah Tinggi Ilmu Sosial Dan Politik ( STISIP) Muhammadiyah Sinjai-Sulawesi Selatan (Online) XIII 1, 2018, Http//StisipmSinjai.Ac.Id/Stisippublishing/Index.Php/JAQ/Article/View/135(6 April 2021)

${ }^{5}$ Intan Mara Mutiara, Penggunaan Media Komunikasi Visual Dalam Meningkatkan Bahasa Reseptif Anak Tunarungu: Penelitian Eksperimen Dengan Desain Single Subject Research Pada Anak Tunarungu Kelas Viii Slb-B Sukapura, UPI Repository (Online), 2013, http://repository.upi.edu/id/eprint/413 (6 April 2021)

$$
{ }^{6} \text { Ibid, }
$$
}


Komunikasi visual dipilih untuk memudahkan siswa penyandang tunarungu untuk dapat menerima penyampain pembelajaran. Kode yang sebagian besar digunakan guru dalam berkomunikasi selama pandemi adalah kode yang diucapkan atau ditulis (kode yang berhubungan dengan penggunaan kata-kata). Tetapi sesungguhnya masih ada kode lain yang sangat penting peranannya dalam komunikasi, yaitu kode atau kode tanpa kata atau nonverbal.

Sewaktu kita mengadakan pembicaraan dengan anak tunarungu, cara yang terbaik yang dapat guru perbuat, ialah mencoba membangkitkan dengan perantaraan lambang-lambang lisan atau visual, dengan arti atau makna serta pengalamanpengalaman yang sudah dimiliki oleh pendengar atau anak tunarungu tersebut. Karena setiap siswa mempunyai suatu perbedaan tanda-tanda dan bunyi yang berlain-lainan, maka guru harus dapat memahami, bahwa tingkat kesulitan tugas untuk anak tunarungu tentu berbeda. Jenis media komunikasi dapat dibedakan anatara lain:

a. Media cetak seperti, surat kabar, majalah, buku, booklet, brosur.

b. Media elektronik seperti, radio, televise, film, video, audio record.

c. Media online sebagai media baru.

Anak tunarungu juga menggunakan media online seperti youtube. Youtube digunakan dalam penyampain materi guru terhadap siswa. Pengiriman tugas sekolah juga menggunakan aplikasi whatsapp. Peristiwa pandemi covid-19 yang terjadi hampir diseluruh dunia ini menunjukan semakin pentingnya peran keluarga dalam mengasuh, merawat, juga mendidik anak.

\section{Pemanfaatan Media Komunikasi Pada Siswa Tunarungu Di SDLB Shanti Kosala Mas Trip Selama Pandemi}

Pemanfaatan Media Komunikasi pada siswa tunarungu yang digunakan ialah media kongkret seperti puzzle, gambar, kartu bergambar dan alat peraga. Pemanfaatan ini termasuk dalam jenis komunikasi verbal. Sedangkan Media merupakan perantara penyampaian materi pembelajaran agar materi yang disampaikan dapat diterima dengan baik oleh peserta didik dengan adanya media tersebut.

Keunggulan media kongkret yaitu memiliki tingkat objektivitas tinggi, fleksibilitas yang tinggi sehingga cocok digunakan pada pembelajaran anak tunarungu, selain itu media kongkret juga dapat dimanipulasi sesuai dengan kebutuhan maupun kondisi serta memudahkan interaksi dengan anak tunarungu. Karena anak tunarungu memiliki tingkat penangkapan dan pemahaman materi yang berbeda.

Media ini termasuk dalam bentuk komunikasi verbal. Komunikasi verbal memang paling sering digunakan selama pandemi. Sedangkan untuk bentuk komunikasi non verbal biasanya hanya dilakuakan pada saat guru melakukan pembelajaran home visit yaitu kunjungan di rumah siswa penyandang tunarungu. 
Untuk home visit sendiri, hanya dilakukan sebulan sekali mengingat himbauan pemerintah untuk memberlakukan kegiatan pembatasan sosial. Namun dengan jadwal kunjungan yang terbatas, kegiatan ini tetap dilakuakan karena selain sebagai kegiatan monitoring guru terhadap siswa penyandang tunarungu, home visit juga dapat pemberi semangat dan dukungan pada siswa penyandang tunuarungu bahwa pada situasi pandemi bukan bearti kita bermalas-malasan dalam menuntut ilmu. Dalam kunjungan home visit wali murid juga dapat menyampaikan segala kendala terhadap guru selama pembelajaran pada saat pandemi. Setelah pengerjaaan penugasan tugas dikumpulkan kepada guru, tugas dapat dikirim melalui media online.

Sarana yang dapat digunakan sebagai media online antara lain, e-learning, aplikasi zoom, google classroom, youtube, maupun media sosial whatsapp. Saranasarana tersebut dapat digunakan secara maksimal, sebagai media dalam melangsungkan pembelajaran seperti di kelas. Dengan menggunakan media online tersebut, maka secara tidak langsung kemampuan menggunakan serta mengakses teknologi semakin dikuasai oleh siswa,wali murid maupun guru.

Pembelajaran yang dilakukan di rumah, dapat membuat orang tua lebih mudah dalam memonitoring atau mengawasi terhadap perkembangan belajar anak secara langsung. Orang tua lebih mudah dalam membimbing dan mengawasi belajar anak dirumah. Hal tersebut akan menimbulkan komunikasi yang lebih intensif dan akan menimbulkan hubungan kedekatan yang lebih erat antara anak dan wali murid.

\section{Upaya Penyampaikan Pesan Kepada Siswa Penyandang Tunarungu Selama Pandemi Di SDLB Shanti Kosala Mas Trip}

Wabah pandemi Covid - 19 yang terjadi di Indonesia mengakibatkan perubahan pola pembelajaran. Pola pembelajaran yang sudah sejak lama dilakukan pada semua satuan Pendidikan selama ini, tiba-tiba terpaksa harus berubah dengan pola pembelajaran online atau dalam jaringan. Perubahan pola pembelajaran ini disebabkan karena adanya kebijakan pemerintah untuk melakukan physical distancing. Perubahan pola pembelajaran ini membuat ketidaksiapan bagi anak tunarungu yang memiliki hambatan pendengaran, baik guru maupun orangtua peserta didik. Ketidaksiapan tersebut berkaitan dengan kurikulum pembelajaran yang didaringkan, teknis dan pelaksanaan maupun faktor penunjang kegiatan pembelajaran Online tersebut. Perubahan cara belajar ini berakibat pada perubahan tingkah laku dan mental peserta didik tunarungu. Perubahan perilaku dan mental tersebut akan berdampak dalam perkembangan peserta didik tunarungu, jika tidak mendampatkan pendampingan belajar secara tepat. Guru SDLB maupun sekolah penyelenggara inklusi diharapkan berperan untuk mengantisipasi dampak perubahan pola belajar yang dialami anak tuanrungu serta mampu memberikan pendampingan secara tepat selama masa pandemi Covid-19. 
Hambatan pendengaran atau istilah tunarungu adalah suatu istilah umum yang menunjukkan ketidakmampuan mendengar dari yang ringan sampai berat, digolongkan ke dalam tuli dan kurang dengar. Seseorang yang mengalami ketunarunguan adalah individu yang kehilangan kemampuan mendengar sehingga menghambat proses informasi bahasa melalui pendengaran, baik memakai ataupun tidak memakai alat bantu dengar di mana batas pendengaran yang dimiliki masih memungkinkan keberhasilan proses informasi bahasa melalui pendengaran.

Cara berkomunikasi untuk menyampaiakan pesan serta interaksi yang terbangun antara guru dan anak tunarungu harus dengan metode yang tepat. Alat komunikasi yang digunakan berupa aplikasi pada gadget atau smartphone. Guru dan anak tunarungu akan tetap terhubung di waktu yang sama walaupun ada di tempat yang berbeda. Tentu dalam kegiatan belajar mengajar secara jarak jauh anak tunarungu harus tetap mendapat bimbingan dari wali murid. Karena Wali murid merupakan guru bayangan dalam kegiatan belajar mengajar di masa pandemi.

Komunikasi dapat berupa video call, telepon, chat maupun video tutorial. Alat-alat komunikasi tersebut juga dapat digunakan secara optimal sebagai sarana pembelajaran untuk anak tunarungu. Satu hal yang tidak boleh dilupakan adalah guru harus memastikan keterlibatan siswa yang harus tetap terbangun walaupun melalui media online.

Keterlibatan anak tunarungu sangat penting karena banyak siswa yang merasa bosan, tidak termotivasi. Melihat kemungkinan ini maka guru harus memastikan keterlibatan siswa. Hal ini menjadi point penting serta tantangan untuk guru pada saat mengajar jarak jauh. Untuk anak tunarungu yang mengikuti PJJ keterlibatan ini juga harus mendapat perhatian disamping strategi belajar khusus yang akan dilakukan.

Guru dapat menyapa peserta didik, menanyakan kabar, menyebut nama satu persatu sebagaimana aktivitias ini dilakukan pada saat tatap muka langsung. Guru juga dapat menyapa orangtua, menanyakan kendala-kendala dan juga memberi apresiasi atas bantuan orangtua selama mendampingi siswa belajar dirumah. Membuat gambar peta emosi dan suasana hati hari ini dapat juga dilakukan dengan menarik diluar sapaan. Mengkonfirmasi instruksi dan memahami aturan juga termasuk dalam aktifitas ini dapat dilakukan berulang-ulang dengan beberapa variasi baik secara tatap maya/ video call maupun via chat. 


\section{SIMPULAN DAN SARAN}

1. Kesimpulan

Berdasarkan data-data deskripsi pada bab-bab sebelumnya, maka dapat diambil kesimpulan bahwa media komunikasi yang digunakan oleh guru dalam proses belajar mengajar terhadap siswa penyandang tunarungu selama pandemi di SDLB Shanti Kosala Mastrip ialah harus dilakukan secara jarak jauh baik luring maupun daring. Penggunaan Media komunikasi anak tunarungu selama pandemi Covid-19 ialah media visual artinya media yang nyata atau kongret dapat dilihat secara langsung seperti media buku, gambar, puzzle, warna, dan penggunaan simbol. Guru memilih media visual, karena anak tunarungu tidak memiliki hambatan penglihatan. Bentuk komunikasi seperti ini termasuk dalam bentuk komunikasi non verbal yang memang memudahkan anak tunarungu melakukan pembelajaran pada saat pandemi Covid-19. Selain itu guru juga dapat menggunakan media aplikasi whatsapp dan channel youtube sekolah.

Kemudian pemanfaatan media komunikasi yang digunakan selama pandemi, guru mengolah buka tugas atau lks dengan metode yang sederhana agar memudahkan anak tunarungu untuk melakukan pembuatan tugas. Siswa juga melakukan kegiatan sehar-hari yang didomuntasi wali murid melalui handphone sebagai salah satu bentuk dari tugas.

Upaya penyampaian pesan anak tunarungu melalui wali murid. Guru dan wali murid harus sering berkomunikasi mengenai pembagian dan pengumpulan tugas siswa tunarungu. Pengumpulan tugas wali murid biasa menggunakan aplikasi whatsapp namun untuk orang tua yang memiliki kendala sinyal dan handphone, bisa langsung datang kesekolah untuk pengambilan tugas selama satu minggu. Wali murid biasanya datang setiap satu minggu sekali selain untuk pengambilan tugas juga pengumpulan tugas sebelumnya. Meski tugas diberikan langsung selama seminggu, tugas tetap dikerjakan secara bertahap sesuai jadwal yang sudah ditentukan. Metode ini dilakukan sebagai upaya memutus mata rantai penyebaran Covid-19.

2. Saran

Berdasarkan hasil penelitian, agar dapat dijadikan acuan untuk penelitian berikutnya serta menjadi motivasi dan bahan masukan, maka ada beberapa saran yang penulis sampaikan terutama kepada guru dan siswa penyandang tunarungu di SDLB Shanti Kosala Mas Trip, hasil penelitian ini diharapkan dapat menjadi bahan agar dapat berinteraksi dengan baik dan sebagai acuan sekoalah inklusi lainnya dalam kegiatan belajar mengajar baik secara daring dan luring selama pandemi Covid-19. 


\section{DAFTAR PUSTAKA}

Mulyana, Dedy. Ilmu Komunikasi Suatu Pengantar, PT Remaja Rosdakarya, Bandung, 2000.

Ngalimun. Ilmu Komunikasi Sebuah Sebuah Pengantar Praktis, Pustaka Buku Ekspres, Bandung, 2017.

Riadi, Slamet. dkk., Identifikasi Dan Evaluasi Anak Luar Biasa, CV. Harapan Baru, Jakarta, 1977.

Astri, Herlina. dkk., Pemenuhan Dan Perlindungan Hak-Hak Penyandang Disabilitas, Pusat Pengkajian, Pengolahan Data Dan Informasi (P3DI), Jakarta: 2014.

Alimuddin, Asriani . Schancya Gillian Wairata, Efektivitas Komunikasi Non verbal Pada Anak Tunarungu Dalam Berkomunikasi Di Slb Rajawali Makassar, AlQisthi Jurnal Sosial Dan Politik-Sekolah Tinggi Ilmu Sosial Dan Politik ( STISIP) Muhammadiyah Sinjai- Sulawesi Selatan (Online) XIII 1, 2018, Http://StisipmSinjai.Ac.Id/Stisippublishing/Index.Php/JAQ/Article/View/135 (6 April 2021)

Delis, Edina Erianti, Komunikasi Nonverbal Guru Pada Penyandang Tunarungu Dalam Proses Belajar Mengajar Di Kelas (Studi Deskriptif Penggunaan Teknik Emblem, Ilustrator, Dan Efect Display Pada Penyandang Tunarungu Di Sekolah Dasar Luar Biasa Negeri Pembina Sulsel Sentra PK.PLK Makassar (Online), 2013, Http://Repositori.UinAlauddin.Ac.Id/10137/(18 Januari 2021)

Khoirun Nida, Fatma Laili, Komunikasi Bagi Anak Berkebutuhan Khusus, AtTabsyir Jurnal Komunikasi Penyiaran Islam (Online)I 2, 2013, Https//Journal.Ianikudus.Ac.Id/Index.Php/Komunikasi/Article/View/341/455 (6 april 2021)

Mutiara, Intan Mara, Penggunaan Media Komunikasi Visual Dalam Meningkatkan Bahasa Reseptif Anak Tunarungu: Penelitian Eksperimen Dengan Desain Single Subject Research Pada Anak Tunarungu Kelas Viii SlbB Sukapura, UPI Repository (Online), 2013, http://repository.upi.edu/id/eprint/413 (6 April 2021)

Wuwungan, Novita, Peran Komunikasi Interpersonal Guru Dan Siswa Tunarungu Dalam Meningkatkan Sikap Kemandirian Anak Berkebutuhan Khusus Di Sekolah Pembina Luar Biasa Provinsi Kalimantan Timur, Ejournal Ilmu Komunikasi (Online) IV 4,2016, Https:Ejournal.ilkom.fisipunmul.Ac.Id/Site/Wpcontetnt/Uploads/2016/11/JU RN AL\%20ONLINE\%20(11-24-16-02-40-17).Pdf (6 april 2021)

Wahyudi ,Sigit. Pemanfaatan Media Komunikasi Dalam Memilih Kuliah Di Universitas Muhammadiyah Malang, Studi Pada Mahasiswa Asal Kalimantan,(Online)2018, https://eprints.umm.ac.id/40752/(2 agustus 2021) 